\title{
Analisis Praktik Manajemen Sumberdaya Keluarga dan Dampaknya Terhadap Kesejahteraan Keluarga di Kabupaten da Kota Bogor
}

\author{
Abubakar Iskandar ${ }^{1}$
}

\section{Ringkasan}

Tujuan penelitian ini adalah untuk menganalisis praktik manajemen sumberdaya keluarga. Desain penelitian ini adalah cross sectional survey dengan melibatkan 240 keluarga sampel yang dipilih seara random di delapan desa. Metode yang digunakan dalam menganalisis data adalah regresi berganda yang mempredisi variabel demografi (jumlah anggota, umur suamu dan isteri), variabel sosial ekonomi (pendidikan suami dan isteri, pendpatan, aset, dan tempat tinggal) yang dapat mempengaruhi manajemen sumberdaya keluarga yang meliputi perencanaan, pembagian tugas dan pegawsan. Hasil pnelitian menunjukkan bahwa tempat tinggal di kota dapat mempengaruhi keluarga dalam melakukan perencanaan, sedangkan keluarga yang tinggal d desa dapat mempengaruhi keluarga dalam melakukan pembagian tugas, sementara itu, keluarga yang emiliki pendapatan yang tinggi dapat meakukan pengawasan.Hasil penlitian menunjukkan bawa 62,5 persen keluaga di kota dan 73,3 persen keluarga di desa yang melakukan perencanaan digolongkan sebagai keuarga yang tidak miskin, sedangkan 50,0 persen keuaga di kiota dan 40,5 persen keluarga di desa yang melakukan pembagian tugas dikategorikan sebagai keluarga miskin. Rata-rata pengeluaran untuk pangan dan non pangan Rp. 197.920.7, per kapita di kota dan ratarata pengelaran pangan dan non pangan di desa Rp. 195.486.7 adalah miskin Alokasi waktu kegiatan pribadi utuk suami di kota adalah 10,2 dikategorikan sebagai keluarga miskin dan di desa adalah 11,1. Alokasi waktu kegiatan pribadi isteri di kota adalah 10,6 dan di desa 11,3 dkategrikan keluarga miskin.

Kata kunci: kesejahteraan, kemiskinan dan manajemen sumberdaya keluarga.

\section{Pendahuluan}

\subsection{Latar Belakang}

Di Indonesia istilah keluarga sejahtera baru dirumuskan oleh pemerintah sejak dikeluarkannya UU No 10 tahun 1992 tentang Perkembangan Kependudukan dan Pembangunan Keluarga Sejahtera. Konsep yang ada sebelumnya adalah kemiskinan yang dikembangkan oleh beberapa pakar seperti: Sayogyo (1999) mengukur tingkat kesejahteran keluarga dengan menggunakan kriteria batas garis kemiskinan berdasarkan satuan kilogram beras ekuivalen. Keluarga miskin adalah keluarga yang mempunyai penghasilan setara dengan $240-320 \mathrm{~kg}$

\footnotetext{
${ }^{1}$ Staf Pengajar Departemen Komunikasi dan Pengembangan Masyarakat FEMA-IPB
} 
beras/tahun untuk daerah perdesaan dan 360-480 kg beras/tahun untuk daerah perkotaan.

Kedua konsep tersebut tetap mengacu kepada pemikiran yang sama, yaitu UUD 1945 pasal 34 ayat 1. Perbedaan mendasar antara definisi tidak sejahtera (pra KS dan KS-I) dengan definisi miskin adalah pada pendekatan analisisnya. Secara umum kedua definisi tersebut menunjuk pada kondisi ketidakmampuan untuk memenuhi kebutuhan dasar seseorang atau rumahtangga (miskin) atau keluarga (tidak sejahtera). Namun definisi miskin dengan menggunakan pendekatan ekonomi menunjuk pada kemampuan keluarga memenuhi kebutuhan hidup berdasarkan sumberdaya yang dimilikinya sehingga ukuran yang digunakan adalah penghasilan atau pengeluaran seseorang/rumahtangga. Dengan demikian, ketika berbicara tentang kemiskinan sama halnya juga berbicara tentang ketidaksejahteraan.

Sumberdaya yang dimiliki keluarga maupun bantuan dari pemerintah terhadap keluarga miskin/tidak sejahtera tidak akan efektif jika tidak di atur secara baik melalui manajemen sumberdaya keluarga yang meliputi perencanaan, pembagian tugas, pelaksanaan dan pengawasan. Dengan demikian, secara internal pemberdayaan mereka yang tergolong powerless menjadi powerfull, manajemen keluarga menjadi sangat penting dalam dalam meningkatkan kesejahteraan keluarga.

\section{Perumusan Masalah}

Berdasarkan ulasan tersebut, dirumuskan beberapa pertanyaan penelitian antara lain: Pertama, sejauhmanakah perencanaan mempengaruhi kesejahteraan keluarga? Kedua, sejauhmanakah pembagian tugas mempengaruhi kesejahteraan keluarga? Ketiga, sejauhmanakah pelaksanaan kegiatan mempengaruhi kesejahteraan keluarga? Keempat, sejauhmanakah pengawasan mempengaruhi kesejahteraan keluarga? Kelima, sejauhmanakah faktor-faktor yang berpengaruh terhadap praktek manajemen keluarga?

\section{Tujuan Penelitian}

Secara umum penelitian ini bertujuan untuk mempelajari secara komprehensif manajemen keluarga yang mempengaruhi kesejahteraan, sedangkan secara khusus tujuan penelitian ini adalah:

1. Menganalisis pengaruh perencanaan terhadap kesejahteraan keluarga

2. Menganalisis pengaruh pembagian tugas terhadap kesejahteraan keluarga

3. Menganalisis pengaruh pelaksanaan tugas terhadap kesejahteraan keluarga

4. Menganalisis pengaruh pengawasan terhadai kesejahteraan keluarga

5. Menganalisis faktor-faktor yang berpengaruh terhadap praktek manajemen keluarga 


\section{METODE}

\section{Desain, Lokasi dan Waktu Penelitian}

Desain penelitian ini adalah cross sectional survey. Penelitian ini dilakukan di Kabupaten Bogor dan Kota Bogor Propinsi Jawa Barat. Penelitian dilakukan bulan April 2006 sampai dengan bulan April 2007.

\section{Teknik Penarikan Contoh}

Contoh dalam penelitian adalah keluarga yang tinggal di Kabupaten dan Kota Bogor. Di Kabupaten Bogor dipilih tiga Kecamatan dan di Kota Bogor dipilih satu kecamatan dan selanjutnya tiap kecamatan dipilih dua kelurahan/desa secara purposive. Tiap desa/kelurahan di ambil keluarga contoh sebesar 30 contoh yang terdistribusi pada kriteria sejahtera menurut BKKBN yaitu Pra-KS, KS-1, KS-2, KS-3 dan KS-3+, sehingga jumlah sampel sebanyak 240 keluarga contoh. Penarikan contoh dilakukan secara proporsional (Proportional Stratified Random Sampling).

Berdasarkan teori penarikan contoh bahwa bila semua kemungkinan contoh acak berukuran $n$ diambil tanpa pemulihan dari suatu populasi terhingga berukuran $N$ yang mempunyai nilai tengah (median) dan standar deviasi maka sebaran penarikan contoh bagi nilai tengah contoh rata-rata (mean) akan menghampiri sebaran normal dengan nilai tengah dan standar deviasi (Walpole, 1995). Dalil ini dapat mendekati kebenaran kalau hasil pengukuran yang ditunjukkan oleh variabel independent mendekati normal. Pentingnya dalil ini terutama untuk membuat kesimpulan mengenai estimator dari sampel yang menurut dalil pusat (central limit theorem) mengikuti atau mendekati fungsi normal, apabila sample cukup besar yaitu kalau $n$ menuju tak terhingga. Dalil ini dalam prakteknya sudah berlaku kalau $n>30$, sebab dalam keadaan seperti ini nilai dari Tabel $t$ untuk alpha tertentu akan mendekati nilai dari tabel normal (Supranto, 2000).

Jumlah keluarga miskin dan tidak miskin tersebut berdasarkan alasan ekonomi yang terdiri dari enam unsur yaitu: (1) makan $<$ dua kali sehari, (2) lantai sebagian besar dari tanah, (3) tidak mempunyai pakaian yang berbeda, (4) makan daging/telur/ikan minimal satu minggu sekali, (5) membeli baju baru minimal sekali setahun, (6) luas lantai rumah rata-rata $<8 \mathrm{~m}^{2} /$ anggota keluarga. Adapun sebaran keluarga contoh seperti pada Tabel 1 Tabel 1: Sebaran Keluarga Contoh berdasarkan Status Kesejahteraan BKKBN

\begin{tabular}{|c|c|c|c|c|c|c|}
\hline \multirow{2}{*}{$\begin{array}{l}\text { Desa/ } \\
\text { Kelurahan }\end{array}$} & \multicolumn{5}{|c|}{ Status Kesejahteraan } & \multirow{2}{*}{ Tota } \\
\hline & Pra KS & KS-1 & $\mathrm{KS}-2$ & KS-3 & $\mathrm{KS}-3+$ & \\
\hline Tegalwar & 1 & 10 & 12 & 5 & 2 & 30 \\
\hline Cicadas & 1 & 23 & 5 & 1 & - & 30 \\
\hline Wanahera & 1 & & & & 1 & \\
\hline
\end{tabular}




\begin{tabular}{|c|c|c|c|c|c|c|}
\hline ng & & 10 & 9 & 9 & & 30 \\
\hline Ciangsana & 4 & 6 & 4 & 13 & 3 & 30 \\
\hline Kopo & 1 & 19 & 6 & 3 & 1 & 30 \\
\hline m Cibeureu & 1 & 17 & 7 & 4 & 1 & 30 \\
\hline Gudang & 1 & 13 & 13 & 2 & 1 & 30 \\
\hline $\begin{array}{l}\text { Babakan } \\
\text { Pasar }\end{array}$ & - & 21 & 7 & 2 & - & 30 \\
\hline \multirow[t]{2}{*}{ Total } & 10 & 119 & 63 & 39 & 9 & \multirow[t]{2}{*}{240} \\
\hline & & $\begin{array}{l}\text { Miskin } \\
129\end{array}$ & & & & \\
\hline
\end{tabular}

\section{Jenis Data dan Cara Pengumpulannya}

Data yang dikumpulkan adalah data primer dan data sekunder. Data primer adalah data yang langsung dari responden melalui wawancara terstruktur dengan menggunakan kuesioner dan observasi. Wawancara yang dilakukan adalah terutama untuk ungkapan-ungkapan verbal dari anggota keluarga. Observasi yang dilakukan adalah terutama untuk melihat kegiatan yang dilakukan oleh keluarga dan lain-lain. Data sekunder diperoleh melalui rekapitulasi hasil pendataan rumahtangga tingkat desa/kelurahan yang dicatat oleh Petugas Lapangan Keluarga Berencana (PLKB). Data penunjang lainnya diperoleh melalui kajian dokumentasi dan kepustakaan dari publikasi/laporan instansi terkait seperti: BPS, BKKBN, dan sebagainya.

\section{Analisis Data}

Fraenkel dan Wallen (1993) mengatakan bahwa analisis data dalam jenis penelitian seperti ini adalah analisis kuantitatif dan analisis kualitatif. Analisis kuantitatif menggunakan jasa statistik untuk menguji hubungan antar variabel penelitian (yang diwujudkan dalam bentuk menguji hipotesis penelitian) melalui analisis regresi logistic. Analisis data yang digunakan untuk menjawab masing-masing tujuan penelitian adalah di ukur dengan regresi logistik. Model umum regresi logistik (Hennekens dan Buring, 1987; Kleinbaurn, 1994) yang digunakan adalah:

$$
\begin{aligned}
& \alpha+\beta_{1} x_{1}+\beta_{2} x_{2}+\beta_{3} x_{3}+\beta_{4} x_{4}+\beta_{5} x_{5}+\beta_{6} x_{6}+\ldots \ldots \ldots \beta_{18} x_{18}+\varepsilon \\
& \mathrm{P}(\mathrm{x})=\frac{\mathrm{e}}{\alpha+\beta_{1} x_{1}+\beta_{2} x_{2}+\beta_{3} x_{3}+\beta_{4} x_{4}+\beta_{5} x_{5}+\beta_{6} x_{6}+\ldots \ldots . ., \beta_{18} x_{18}+\varepsilon} \\
& 1+\mathrm{e} \\
& \text { dimana: }
\end{aligned}
$$




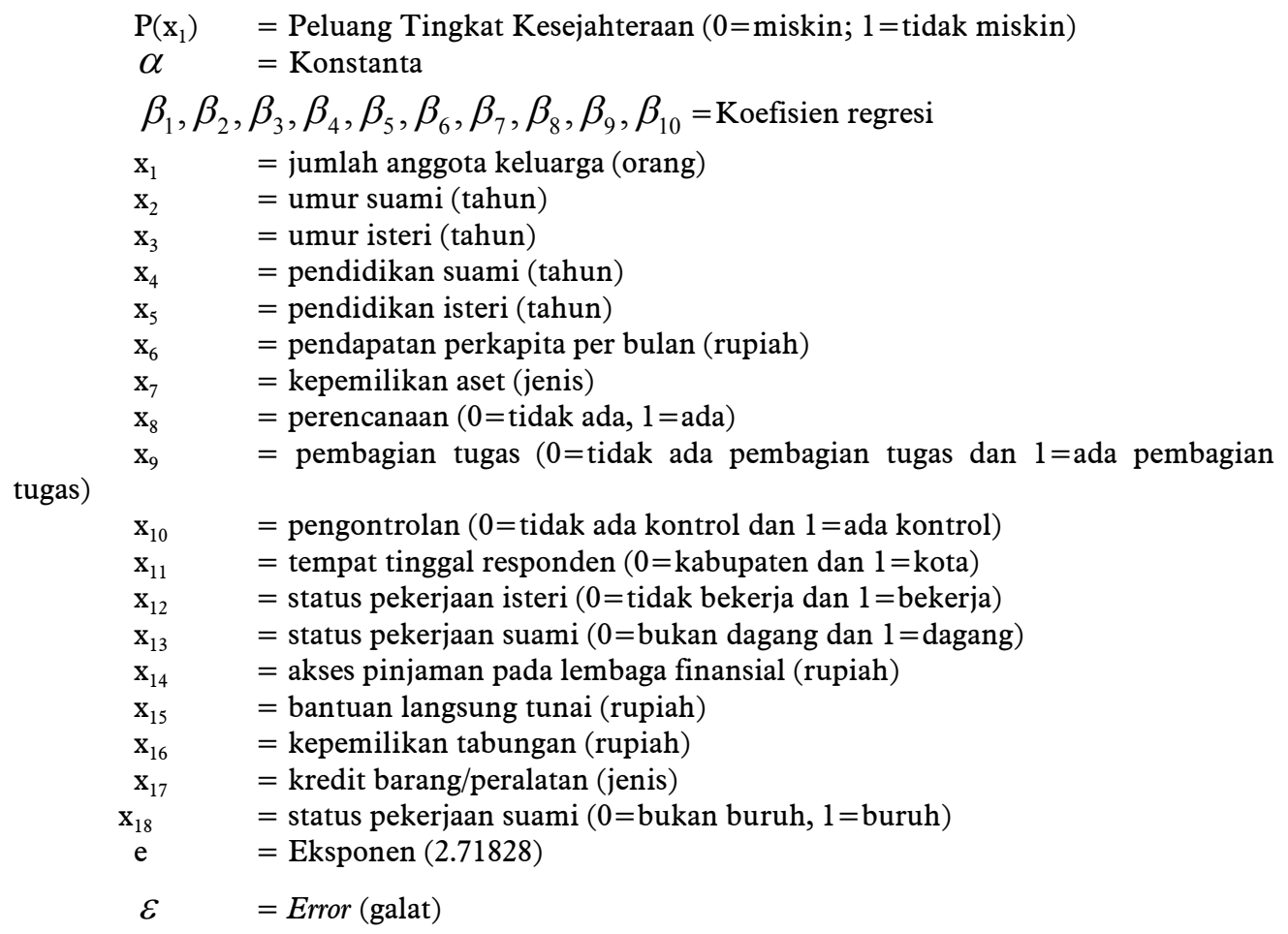

Untuk analisis hipotesis kerja, terlebih dahulu membakukan penduga koefisien regresi (standar estimate), untuk mengetahui sumbangan pengaruh suatu independen variabel kepada variabel dependen yang kemudian ditandai dengan notasi $b^{\star}$, dan membandingkannya dengan nilai $\mathrm{p}$ (nilai probabilitas), yaitu untuk keperluan menguji nyata tidaknya sumbangan pengaruh tersebut. Apabila sumbangan faktor tersebut bernilai $\mathrm{p}<0,05$ akan disebut "tidak berpengaruh nyata", sedangkan jika $\mathrm{p}>0,05$, akan disebut "berpengaruh nyata", dan ditetapkan tingkat kepercayaan 95 persen karena subyek penelitian ini adalah bidang penelitian sosial dan merupakan analisis terhadap keluarga yang sering berubah kehidupannya, sehingga tingkat kepercayaan tersebut dipandang cukup dapat diterima. Sutopo (1990) mengemukakan bahwa untuk melengkapi analisis kuantitatif, dilakukan analisis deskriptif-kualitatif.

Analisis kualitatif ditempuh dengan menerapkan teknik analisis isi. Penerapan teknik content analysis (analisa isi) melalui langkah-langkah: reduksi data, display data, dan cara penarikan kesimpulan. Cara analisis ini pada dasarnya akan dilakukan sejak peneliti berada di lapangan dan mengadakan klasifikasi atas kecenderungan data dari catatan lapangan tersebut. Setiawan dan Muntaha (2000) mengatakan, content analysis adalah penelitian yang bersifat pembahasan mendalam terhadap isi suatu informasi, dan biasanya yang menjadi sumber penelitian adalah data verbal. Dengan demikian, wawancara menjadi sangat penting dalam analisis ini. Prosedur teknik content analysis tersebut dilakukan dengan mengadaptasi prosedur yang disarankan Miles dan Heberman dalam Sutopo (1990) terutama bila didapatkan dari kajian teori tertentu berhubungan dengan temuan tematik tertentu, maka peneliti membuat 
kemungkinan elaborasi konseptual atas kecenderungan data yang ada tersebut. Kasus-kasus temuan tematik digabungkan satu dengan yang lain, dan kemudian dibuat dalam bentuk ringkasan data, yaitu usaha membuat sintesis atas apa yang diketahui peneliti dari data sebagai cara menarik kesimpulan yang di teliti secara kualitatif.

\section{Uji Reliabilitas Data}

Uji reliabilitas dilakukan dengan menggunakan metode inter-item corelation atau internal konsistensi Cronbach Alpha untuk mengukur keterandalan suatu pengukuran. Rumus yang digunakan adalah Cronbach yang diekspresikan dengan: Alpha $=\mathrm{N}^{-} \mathrm{p} /[1+\mathrm{p}(\mathrm{N}-1)]$. Pengujian ini dilakaukan dengan tujuan agar setiap indikator masing-masing peubah yang digunakan dalam model dapat diketahui kehandalannya. Instrumen telah reliabel digunakan apabila nilai Cronbach $>0.6$. Keterangan: $\mathrm{N}$ adalah jumlah butir pertanyaan pengukuran dan ${ }^{-} \mathrm{p}$ adalah rata-rata dari korelasi inter-item.

\section{Komunikasi dalam pembuatan rencana}

\section{HASIL DAN PEMBAHASAN}

Keterbatasan sumberdaya yang dimiliki oleh sebuah keluarga menyebabkan perlunya suatu pengelolaan yang baik agar tujuan hidup yang diinginkan dapat tercapai. Langkah awal yang dapat dilakukan adalah dengan membuat suatu perencanaan. Hasil penelitian menunjukkan bahwa lebih dari separuh $(62.5 \%)$ responden di kota, dan $73.3 \%$ responden di desa memiliki perencanaan dalam mencapai tujuan hidup, dan keluaraga yang memilikii rencana ini tergolong tidak miskin. Sebanyak $80.8 \%$ responden di kota dan $82.4 \%$ responden di desa mengatakan rencana perlu dibuat agar tujuan hidup dapat tercapai, dan ternyata mereka ini tergolong tidak miskin.

Sebaliknya, sebagian besar responden di kota maupun responden di desa membiarkan tujuan hidup mengalir seperti apa adanya, namun sebanyak $100.0 \%$ di kota dan $85.3 \%$ responden di desa yang mengatakan membiarkan tujuan hidup mengalir seperti apa adanya adalah tergolong miskin. Pembuatan perencanaan dapat dilakukan dengan cara tertulis, akan tetapi hasil penelitian memperlihatkan bahwa sebagian besar (97.2\%) responden di kota dan 100.0\% responden di desa membuat perencanaan yang tidak tertulis, dengan alasan cukup diingat saja, tetapi mereka ini termasuk keluarga miskin.

Dari empat orang responden di desa yang melakukan perencanaan tertulis, diantaranya beralasan agar kegiatan dapat berjalan sesuai dengan target dan lebih jelas. Dalam pembuatan perencanaan, lebih dari separuh (75.0\%) ibu di daerah perkotaan dan 94.0 ibu di daerah perdesaan mengkomunikasikan dengan pasangan hidupnya (bapak) dengan alasan agar keduanya sama-sama berusaha mewujudkan rencana yang telah dibuat. Dari 15 responden di kota dan 38 responden di desa yang tidak 
berkomunikasi dengan bapak, disebabkan karena memang tidak ada sesuatu yang perlu direncanakan sehingga komunikasi juga tidak harus dilakukan.

Selain pasangan hidupnya (bapak), pembuatan suatu rencana yang dilakukan oleh ibu terkadang juga melibatkan anggota keluarga lainnya seperti anak dan saudara. Hasil penelitian menunjukkan bahwa lebih dari separuh (65.0\%) responden di kota berkomunikasi dengan anak, sedangkan $76.2 \%$ responden di desa juga melakukan hal yang sama. Dari 34 responden di kota dan 51 responden di desa yang melakukan komunikasi dengan anak, berasan bahwa anak dapat dijadikan sebagai tempat bertukar pikiran. Sebaliknya tidak diikutsertakannya anak untuk berkomunikasi dalam pembuatan perencanaan oleh $92.8 \%$ responden di kota dan $76.8 \%$ responden di desa diantaranya disebabkan karena anak yang dimiliki oleh responden masih kecil, dan masingmasing keluarga tersebut tergolong miskin dan tidak miskin. .

Hasil penelitian memperlihatkan juga bahwa sebagian besar responden di kota maupun di desa tidak melakukan komunikasi dengan saudara dalam pembuatan rencana. Sebanyak 18 responden di kota dan 12 responden di desa yang mengkomunikasikan rencana dengan saudara beralasan bahwa saudara merupakan anggota keluarga yang dapat dijadikan tempat bertukar pikiran. Sebaliknya dari 34 responden di kota dan 166 responden di desa yang tidak berkomunikasi dengan saudara, sebagian besar (63.9\%) responden di kota dan $92.4 \%$ responden di desa beranggapan bahwa pembuatan perencanaan tidak perlu merepotkan orang lain, dan mereka ini termasuk keluarga miskin..

Keterlibatan pihak lain di luar keluarga dalam pembuatan rencana juga terjadi pada beberapa keluarga. Akan tetapi sebagian besar (95.8\%) responden di kota dan $97.8 \%$ responden di desa tidak melakukan komunikasi dengan pihak lain dalam pembuatan rencana. Dari 4 responden di kota dan 5 responden di desa yang melibatkan pihak lain, beralasan bahwa pihak lain dapat digunakan sebagai tempat bertukar pikiran. Sebaliknya, responden di kota maupun responden di desa yang tidak berkomunikasi dengan pihak lain memiliki anggapan bahwa komunikasi dengan pihak lain tidaklah diperlukan karena komunikasi dapat dilakukan dalam keluarga saja.

Sebagian besar (97.7\%) responden di kota dan $84.8 \%$ responden di desa tidak membuat perencanaan secara terperinci, dan mereka ini tergolong miskin. Pembuatan perencanaan yang tidak terperinci oleh 53 responden di kota dan 151 responden di desa, beralasan hanya garis besar saja. Sebaliknya responden di kota dan responden di desa yang membuat rencana terperinci beranggapan bahwa hal tersebut diperlukan agar rencana menjadi lebih terarah. Secara umum sebesar $71.2 \%$ memiliki rencana, dan keluarga tersebut termasuk tidak miskin, sedangkan $53.9 \%$ yang memiliki rencana namun tergolong miskin. Sebanyak $92.0 \%$ responden membuat rencana tidak tertulis dan mereka ini termasuk tidak miskin sedangkan $99.1 \%$ yang membuat rencana tidak tertulis tergolong miskin. Dalam pembuatan rencana sebanyak $90.4 \%$ dikomunikasikan dengan bapak dan mereka ini tergolong tidak miskin, sedangkan $62.6 \%$ yang mengkomunikasikan dengan bapak termasuk 
miskin. Sebanyak $62.4 \%$ mengkomunikasikan dengan anak ketika membuat rencana, dan keluarga ini termasuk tidak miskin, sedangkan $62.6 \%$ mengkomunikasikan dengan anak ketika membuat rencana tergolong miskin. Sebesar $83.2 \%$ tidak mengkomunikasikan dengan saudara ketika membuat rencana dan mereka ini tergolong tidak miskin, sedangkan $83.5 \%$ yang tidak mengkomunikasikan dengan saudara ketika membuat rencana, tergolong miskin. Sebesar $96.8 \%$ tidak mengkomunikasikan dengan pihak lain ketika membuat rencana dan mereka ini tergolong tidak miskin, sedangkan $94.8 \%$ yang tidak mengkomunikasikan dengan pihak lain ketika membuat rencana, tergolong miskin. Sebesar $83.2 \%$ responden membuat rencana tidak terperinci dan mereka ini tergolong tidak miskin, sedangkan $86.9 \%$ responden membuat rencana tidak terperinci, tergolong miskin. Secara rinci dapat dilihat pada Lampiran 1

\section{Pembagian Tugas dalam Keluarga}

Berdasarkan hasil analisis dapat dilihat bahwa lebih dari separuh (50.0\%) responden di kota dan $40.5 \%$ responden di desa melakukan pembagian tugas, namun mereka ini tergolong miskin. Hasil penelitian menunjukkan bahwa sebanyak $31.6 \%$ ibu di kota dan $92.0 \%$ ibu di desa berperan sebagai ibu rumah tangga yang memiliki tugas mengurus anak dan rumah tangga, dan ibu rumahtangga ini tergolong miskin, sedangkan sebesar (90.0\%) suami di kota dan sebagian besar $(84,6 \%)$ suami di kota bertugas untuk mencari nafkah, dan mereka ini tergolong tidak miskin. Anak sebagai anggota keluarga lainnya, sebagian besar (93.3) anak di kota dan $81.8 \%$ anak di desa hanya memiliki kewajiban untuk belajar. Adanya pembagian tugas yang jelas antara tiap anggota sangatlah diperlukan agar rencana yang telah ditetapkan dapat berjalan sesuai tujuan yang diinginkan.

Secara umum responden menetapkan pembagian tugas pada masing-masing anggota. Sebagian besar (67.3\%) ibu bertugas mengurus anak dan rumahtangga dan keluarga ini tergolong tidak miskin, sedangkan sebesar $65.9 \%$ termasuk miskin. Sebesar $88.6 \%$ bapak bertugas lebih banyak mencari nafkah dan keluarga ini termasuk tidak miskin, sedangkan $100 \%$ termasuk keluarga miskin. Sebagian besar (85.9\%) anak bertugas untuk belajar dan keluarga ini termasuk tidak miskin, sedangkan $63.6 \%$ anak yang bertugas untuk belajar termasuk keluarga yang miskin. Secara rinci seperti dalam Tabel 2.

Tabel 2: Sebaran Pembagian Tugas Keluarga Contoh dan Tingkat Kesejahteraan

\begin{tabular}{|c|c|c|c|c|c|c|c|c|c|c|c|c|}
\hline \multirow[t]{3}{*}{ Pernyataan } & \multicolumn{4}{|c|}{ Kota } & \multicolumn{4}{|c|}{ Desa } & \multicolumn{4}{|c|}{ Total (Kota+Desa) } \\
\hline & \multicolumn{2}{|c|}{$\begin{array}{c}\text { Miskin } \\
(36)\end{array}$} & \multicolumn{2}{|c|}{$\begin{array}{c}\text { Tdk Miskin } \\
\text { (24) }\end{array}$} & \multicolumn{2}{|c|}{$\begin{array}{c}\text { Miskin } \\
(79) \\
\end{array}$} & \multicolumn{2}{|c|}{$\begin{array}{c}\text { Tdk Miskin } \\
(101)\end{array}$} & \multicolumn{2}{|c|}{$\begin{array}{c}\text { Miskin } \\
(115) \\
\end{array}$} & \multicolumn{2}{|c|}{$\begin{array}{c}\text { Tdk Mis } \\
(125) \\
\end{array}$} \\
\hline & $\mathrm{n}$ & $\%$ & $\mathrm{n}$ & $\%$ & $\mathrm{n}$ & $\%$ & $\mathrm{n}$ & $\%$ & $\mathrm{n}$ & $\%$ & $\mathrm{n}$ & $\%$ \\
\hline 1.Ada pembagian & & & & & & & & & & & & \\
\hline
\end{tabular}




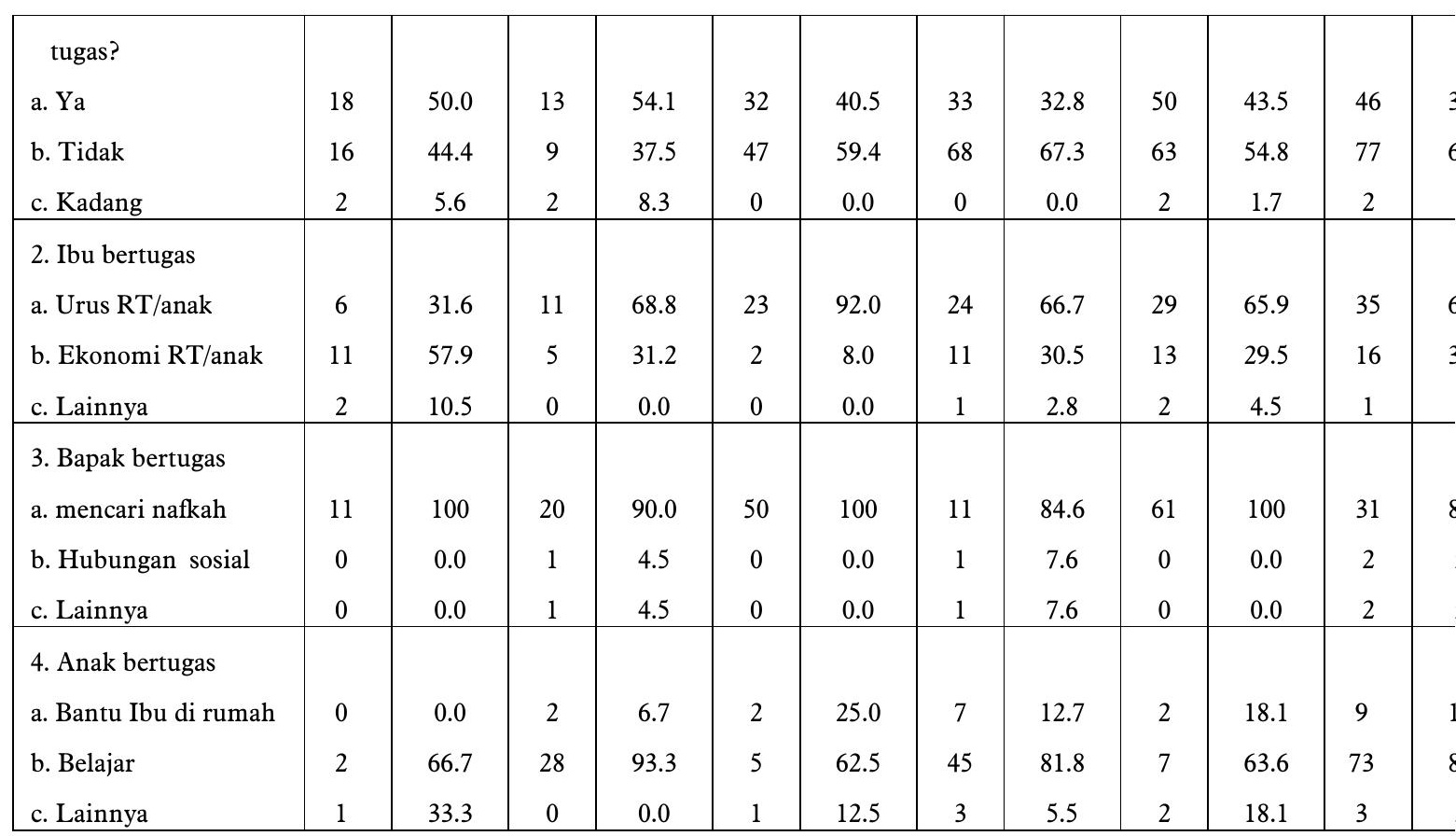

\section{Pelaksanaan}

Pelaksanan adalah upaya mendistribusikan sumberdaya yang dimiliki oleh keluarga dengan cukup baik sehingga dapat tercapai tujuan yang telah ditentukan sebelumnya. Adapun pendistribusian sumberdaya adalah sejauhmana keluarga dapat mengalokasikan sumberdaya uang dan sumberdaya waktu untuk memenuhi kebutuhan.

\section{a. Alokasi Pengeluaran Keluarga}

Tingkat kesejahteraan masyarakat dapat dijelaskan melalui besarnya pendapatan yang diterimanya setiap bulan atau setiap tahun. Dengan demikian pendapatan keluarga adalah besarnya rata-rata penghasilan yang diperoleh dari seluruh anggota keluarga (Susanti,1999). Namun, idiom-idiom tentang tingkat kesejahteraan masyarakat melalui pendekatan pendapatan sangat sulit dilakukan karena masyarakat pada umumnya sukar untuk mencatat dan mengingat arus pendapatan serta jenisnya atau juga oleh sebab-sebab lain. Oleh karena itu, pendapatan keluarga dibedakan menurut pengeluaran untuk makanan dan bukan makanan. Kedua jenis pengeluaran ini dapat menjelaskan dengan cukup baik bagaimana pola konsumsi masyarakat secara umum (Rambe, 2005).

Pengeluaran pangan rata-rata per kapita per bulan adalah biaya yang dikeluarkan untuk konsumsi semua anggota rumah tangga selama sebulan dibagi dengan banyaknya anggota keluarga. Suhardjo (1989) menyatakan bahwa pendapatan sangat berpengaruh terhadap alokasi pengeluaran keluarga. Keluarga yang memiliki pendapatan yang rendah akan menggunakan sebagian besar pendapatannya untuk pangan sebagai kebutuhan pokok, sedangkan 
tingkat pendapatan yang baik akan memberi peluang lebih besar untuk pangan yang baik berdasarkan kuantitas dan kualitas.

Hasil penelitian menunjukkan bahwa rata-rata pengeluaran perkapita per bulan untuk pangan di daerah perkotaan yang berstatus miskin sebesar Rp. 197.920.7, sedangkan untuk daerah perdesaan yang tergolong miskin adalah sebesar Rp. 195.486.7. dan untuk pangan di daerah perkotaan yang tergolong miskin adalah sebesar Rp. 169.770.4, sedangkan di daerah perdesaan yang tergolong miskin adalah sebesar Rp. 155.708.2. Jika dilihat berdasarkan jenis pangannya maka komponen pengeluaran terbesar adalah untuk pangan hewani baik di daerah perkotan maupun di daerah perdesaan. Jenis pangan hewani yang sering dikonsumsi oleh sebagian besar keluarga adalah telur, daging ayam, ikan asin dan sebagian kecil adalah daging sapi.

Sementara itu, proporsi terbesar kedua adalah konsumsi makanan dan minuman jadi baik di daerah perkotaan maupun daerah perdesaan. Pengeluaran untuk konsumsi padi-padian menempati urutan ketiga. Hal yang cukup menarik dalam pola pengeluaran ini adalah besarnya pengeluaran untuk tembakau dan sirih baik di daerah perkotaan yang berstatus miskin ( $R p$ 14.967.3), sedang di daerah perdesaan adalah Rp. 25.083.1 Tingginya pengeluaran tersebut disebabkan adanya kebiasaan merokok terutama pada kepala keluarga, dimana dalam sehari dapat menghabiskan minimal 1 bungkus rokok. Untuk jenis pangan lainnya, besarnya pengeluaran pada umumnya masih dibawah Rp 10000 per kapita per bulan. Hasil penelitian juga memperlihatkan bahwa komponen pengeluaran non pangan perkapita per bulan terbesar untuk bahan bakar di daerah perkotaan yang berstatus miskin adalah sebesar Rp. 71.902.5, sedangkan di daerah perkotaan adalah sebesar Rp. 40.057.4.

Tingginya pengeluaran tersebut disebabkan naiknya harga bahan bakar pada saat ini termasuk minyak tanah yang banyak digunakan oleh sebagian besar keluarga. Selain minyak tanah, bahan bakar yang banyak digunakan oleh keluarga adalah bensin untuk kendaraan bermotor dan sebagian kecil mobil yang dimiliki keluarga. Komponen pengeluaran terbesar kedua per kapita per bulan di daerah perkotaan yang berstatus miskin adalah pendidikan (Rp.34.616.6), sedangkan di daerah perdesaan adalah Rp.26.887.5 Tingginya biaya pendidikan tersebut disebabkan oleh tingginya biaya transportasi dan uang saku yang diberikan kepada anak. Hasil uji $t$ menunjukkan adanya perbedaan yang nyata $(p<0.05)$. Rata-rata pengeluaran pangan di daerah perkotaan adalah Rp.205.563.7/kap/bln, sedangkan di daerah perdesaan adalah Rp. 246.923.2/kap/bln. Sebaliknya, hasil uji $t$ menunjukkan adanya perbedaan yang nyata $(\mathrm{p}<0.05)$. Rata-rata pengeluaran non pangan di daerah perkotaan adalah Rp.190.132.2/kap/bln, sedangkan di daerah perdesaan adalah Rp. 209.772.7/kap/bln.

Tingginya pengeluaran tersebut disebabkan naiknya harga bahan bakar pada saat ini termasuk minyak tanah yang banyak digunakan oleh sebagian besar keluarga. Selain minyak tanah, bahan bakar yang banyak digunakan oleh keluarga adalah bensin untuk kendaraan bermotor dan sebagian kecil mobil 
yang dimiliki keluarga. Komponen pengeluaran terbesar kedua per kapita per bulan di daerah perkotaan adalah pendidikan (Rp.44 975.2), sedangkan di daerah perdesaan adalah Rp.38.177.40. Tingginya biaya pendidikan tersebut disebabkan oleh tingginya biaya transport dan uang saku yang diberikan kepada anak

Hasil uji $t$ menunjukkan adanya perbedaan yang nyata $(\mathrm{p}<0.05)$. Ratarata pengeluaran pangan di daerah perkotaan yang tergolong miskin adalah Rp.197.920.7/kap/bln, sedangkan di daerah perdesaan adalah Rp. 195.486.7/kap/bln. Sebaliknya, hasil uji $t$ menunjukkan adanya perbedaan yang nyata $(\mathrm{p}<0.05)$. Rata-rata pengeluaran non pangan di daerah perkotaan yang beerstatus miskin adalah Rp.169.770.4/kap/bln, sedangkan di daerah perdesaan adalah Rp. 155.708.2/kap/bln. Secara umum rata-rata pengeluaran untuk pangan per kapita per bulan adalah Rp.236.583.3, sedangkan pengeluaran untuk non pangan adalah sebesar Rp.204.862.6 Secara lengkap dilihat pada Lampiran 2.

Apabila dilihat dari tingkat kesejahteran berdasarkan pengeluaran pangan maka pada penelitian ini ditemukan bahwa persentase pengeluaran pangan baik di daerah perkotaan maupun daerah perdesaan lebih besar dibandingkan dengan pengeluaran untuk non pangan. Rata-rata persentase pengeluaran pangan di daerah perkotaan yang berstatus miskin adalah sebesar 58.9, sedangkan rata-rata persentase pengeluaran pangan di desa adalah 52.9. Sementara itu, rata-rata persentase pengeluaran non pangan di kota yang berstatus miskin adalah 41.1, sedangkan rata-rata persentase pengeluaran non pangan di desa adalah 39.7. Secara umum persentase pengeluaran untuk pangan sebesar 57.4, sedang untuk non pangan sebesar 42.5.

Hal ini sesuai dengan pendapat Soekirman (1991) bahwa di negara berkembang seperti Indonesia, pengeluaran untuk pangan masih merupakan bagian terbesar $(>50 \%)$. Pola pengeluaran rumah tangga dapat mencerminkan tingkat kehidupan suatu masyarakat. Indikator yang digunakan untuk mengukur tingkat kesejahteraan adalah komposisi pengeluaran untuk makanan dan non makanan. Kesejahteraan dikatakan baik jika persentase pengeluaran untuk makanan semakin kecil dibanding dengan total pengeluaran. Hasil penelitian menunjukkan bahwa pengeluaran keluarga miskin menitikberatkan pada pemenuhan kebutuhan sehari-hari seperti beras dan lauk pauk. Secara rinci dapat dilihat pada Lampiran 3.

\section{b. Alokasi Waktu Kegiatan Suami dan Isteri}

Hasil penelitian menunjukkan bahwa rata-rata waktu yang dialokasikan oleh suami untuk kegiatan produktif (8.4), tergolong tidak miskin, sedangkan rata-rata kegiatan produktif suami di daerah perdesaan sebesar 7.9, tergolong tidak miskin. Alokasi rata-rata kegiatan pribadi suami di daerah perkotaan $(10.5 \mathrm{jam})$, sedangkan alokasi rata-rata kegiatan prabadi di daerah perdesaan (11.3 jam) adalah berstatus tidak miskin. Dengan demikian alokasi rata-rata waktu kegiatan pribadi adalah yang terbanyak jika dibandingkan kegiatan lainnya. 
Keadaan yang hampir sama yaitu alokasi rata-rata kegiatan pribadi isteri di daerah perkotaan sebesar 11.1, sedangkan alokasi rata-rata kegiatan pribadi isteri di daerah perdesaan sebesar 11.3, dan mereka ini tergolong tidak miskin. Di lain pihak, hasil penelitian menunjukkan bahwa Isteri responden yang sebagian besar hanya menjadi ibu rumah tangga terlihat pula dari besarnya waktu isteri untuk kegiatan domestik di daerah perkotaan (5.6 jam) per hari, sedang di daerah perdesaan (5.3 jam) per hari yang mencakup kegiatan memasak, mengasuh anak, mencuci, menyetrika dan membereskan rumah, dan mereka ini tergolong juga tidak miskin. Secara umum rata-rata kegiatan produktif suami contoh di wilayah ini adalah 8.0 jam per hari, dan keluarga ini termasuk tidak miskin, sedangkan rata-rata kegiatan produktif suami contoh sebesar 7.8 jam perhari adalah miskin. Secara lengkap dapat dilihat pada Tabel 3 .

Tabel 3: Jumlah Alokasi Waktu Kegiatan Suami Contoh dan Tingkat Kesejahteraan

\begin{tabular}{|c|c|c|c|c|c|c|c|c|c|c|c|}
\hline \multirow{3}{*}{$\begin{array}{l}\text { Jenis } \\
\text { Kegiatan }\end{array}$} & \multicolumn{4}{|c|}{$\operatorname{Kota}(\mathrm{n}=51)$} & \multicolumn{4}{|c|}{ Desa $(n=173)$} & \multicolumn{3}{|c|}{ Total $($ Kota + Desa $)(n=224)$} \\
\hline & \multicolumn{2}{|c|}{ Miskin } & \multicolumn{2}{|c|}{ Tdk Miskin } & \multicolumn{2}{|c|}{ Miskin } & \multicolumn{2}{|c|}{ Tdk Miskin } & \multicolumn{2}{|c|}{ Miskin } & \multirow{2}{*}{$\begin{array}{l}\text { Tdk Mis } \\
\begin{array}{c}\text { Rata- } \\
\text { rata }\end{array} \\
\end{array}$} \\
\hline & $\begin{array}{c}\text { Rata- } \\
\text { rata }\end{array}$ & Std & $\begin{array}{c}\text { Rata- } \\
\text { rata }\end{array}$ & Std & $\begin{array}{c}\text { Rata- } \\
\text { rata }\end{array}$ & Std & $\begin{array}{c}\text { Rata- } \\
\text { rata }\end{array}$ & Std & $\begin{array}{c}\text { Rata- } \\
\text { rata }\end{array}$ & Std & \\
\hline Produktif & 7.7 & 4.7 & 8.4 & 4.6 & 7.8 & 4.3 & 7.9 & 3.0 & 7.8 & 4.4 & 8.0 \\
\hline Luang & 3.9 & 3.1 & 3.8 & 2.9 & 4.3 & 3.4 & 4.1 & 2.6 & 4.1 & 3.2 & 4.1 \\
\hline Pribadi & 10.2 & 2.0 & 10.5 & 2.1 & 11.1 & 1.8 & 11.3 & 1.9 & 10.8 & 1.9 & 11.2 \\
\hline Sosial & 1.1 & 2.0 & 0.7 & 1.8 & 0.5 & 1.3 & 0.3 & 0.8 & 0.6 & 1.6 & 0.4 \\
\hline Domestik & 1.1 & 1.8 & 0.6 & 2.2 & 2.6 & 0.9 & 0.3 & 1.0 & 0.5 & 1.3 & 0.4 \\
\hline
\end{tabular}

Keterangan:16 suami telah meninggal

Menurut Guhardja et al (1992) pada umumnya pekerjaan rumah tangga sampai saat ini masih dianggap sebagai pekerjaan sektor domestik yang tidak produktif dan tanggung jawab serta beban pekerjaan terletak pada isteri, sehingga curahan waktu isteri terhadap pekerjaan rumah tangga lebih tinggi jika dibandingkan dengan suami. Waktu kegiatan isteri yang sangat menonjol adalah kegiatan pribadi. Waktu kegiatan pribadi untuk isteri yang di daerah perkotaan adalah 10.8 jam per hari sedangkan di daerah perdesaan adalah 11.5 jam per hari. Meskipun demikian, suami juga berperan dalam kegiatan domestik walaupun dengan rata-rata alokasi waktu yang jauh lebih sedikit. Umumnya peran suami dalam pekerjaan domestik adalah membantu pengasuhan anak, sedangkan kegiatan produktif, kegiatan waktu luang, kegiatan pribadi maupun kegiatan sosial, waktu yang dialokasikan suami dan istri cenderung hampir sama.

Aktivitas luang yang umumnya dilakukan oleh suami maupun istri adalah menonton TV dan santai. Dengan demikian dapat disimpulkan bahwa peran suami adalah sebagai pencari nafkah keluarga dan peran domestik isteri sebagai ibu rumah tangga masih dominan. Secara umum rata-rata kegiatan 
produktif isteri contoh di wilayah ini adalah 2.7 jam per hari, dan keluarga ini termasuk tidak miskin, sedangkan rata-rata kegiatan produktif 2.8 jam perhari adalah miskin. Secara rinci dapat dilihat pada Tabel 4.

Tabel 4: Jumlah Alokasi Waktu Kegiatan Isteri Contoh dan Tingkat Kesejahteraan

\begin{tabular}{|c|c|c|c|c|c|c|c|c|c|c|c|c|}
\hline \multirow{3}{*}{$\begin{array}{l}\text { Jenis } \\
\text { Kegiatan }\end{array}$} & \multicolumn{4}{|c|}{ Kota $(n=51)$} & \multicolumn{4}{|c|}{ Desa $(n=173)$} & \multicolumn{4}{|c|}{ Total $($ Kota + Desa $)(n=234)$} \\
\hline & \multicolumn{2}{|c|}{ Miskin } & \multicolumn{2}{|c|}{ Tdk Miskin } & \multicolumn{2}{|c|}{ Miskin } & \multicolumn{2}{|c|}{ Tdk Miskin } & \multicolumn{2}{|c|}{ Miskin } & \multicolumn{2}{|c|}{ Tdk Mis } \\
\hline & $\begin{array}{c}\text { Rata- } \\
\text { rata }\end{array}$ & Std & $\begin{array}{c}\text { Rata- } \\
\text { rata }\end{array}$ & Std & $\begin{array}{c}\text { Rata- } \\
\text { rata }\end{array}$ & Std & $\begin{array}{c}\text { Rata- } \\
\text { rata }\end{array}$ & Std & $\begin{array}{c}\text { Rata- } \\
\text { rata }\end{array}$ & Std & $\begin{array}{r}\text { Rata- } \\
\text { rata }\end{array}$ & \\
\hline Produktif & 3.9 & 4.9 & 2.2 & 3.9 & 2.4 & 3.9 & 2.9 & 3.9 & 2.8 & 4.3 & 2.7 & \\
\hline Luang & 3.9 & 2.3 & 4.0 & 1.9 & 4.6 & 3.0 & 3.7 & 2.6 & 4.4 & 2.8 & 3.8 & 2 \\
\hline Pribadi & 10.6 & 2.1 & 11.1 & 2.1 & 11.3 & 2.3 & 11.7 & 2.1 & 11.1 & 2.3 & 11.5 & 2 \\
\hline Sosial & 0.8 & 1.9 & 1.1 & 1.9 & 0.4 & 0.9 & 0.4 & 1.9 & 0.5 & 1.3 & 0.5 & \\
\hline Domestik & 4.8 & 3.3 & 5.6 & 4.2 & 5.3 & 3.1 & 5.3 & 3.1 & 5.2 & 3.1 & 5.4 & \\
\hline
\end{tabular}

Keterangan: 6 isteri telah meninggal

Jika kita perhatikan alokasi waktu kegiatan produktif suami, menggambarkan bahwa suami menghabiskan waktu produktif tiga kali lebih banyak dibandingkan isteri, yang mengindikasikan bahwa sebagian besar isteri tidak bekerja untuk menopang pendapatan keluarga.Terlepas dari alokasi waktu kegiatan yang berbeda secara kuantitatif di atas, namun dalam perspektif jender, terkesan isteri bekerja di luar rumah tidak dipermasalahkan sepanjang bekerjanya tidak akan melupakan tugas utama karena bekerjanya isteri adalah juga untuk kesejahteran keluarga. Jika ditelusuri lebih jauh terdapat pola hubungan sosial yang menurut Tomagola dalam Sugiarti (1995) sangat ditentukan oleh budaya yang menjadi rujukan normative. Pola hubungan yang berkembang pada keluarga sample adalah pola hubungan equal partner, yaitu suatu pola dimana suami maupun isteri bisa berperan ganda bila keadaan menuntut, siapa saja dapat melakukan sesuatu hal secara fungsional, saling melengkapi, saling terbuka, dan saling membantu sehingga perlu ditopang oleh sikap kedewasaan dan toleransi yang tinggi dari kedua belah pihak.

\section{Pengawasan}

Pengawasan adalah proses pengamatan sekaligus dilakukan evaluasi dan perbaikan jika terjadi kesalahan atau penyimpangan di dalam kegiatan tersebut. Dalam melaksanakan kegiatan sehari-hari, sebesar $55.0 \%$ responden di kota tidak melakukan pengontrolan atas tugas yang dilaksanakan, sedangkan $24.4 \%$ responden di desa saling mengingatkan jika ada kesalahan yang dilakukamn. Sebagian besar (72.2\%) isteri di kota melakukan kegiatan kontrol pada kegiatan yang dilakukan oleh anak dan segala macam urusan rumah tangga, sedangkan di desa $85.4 \%$, masing-masing dengan status miskin dan tidak miskin. Sebanyak $75.0 \%$ suami di kota mencari nafkah, sedang di desa 
$32.3 \%$, dan mereka ini tergolong tidak miskin. Kontrol atas kegiatan yang dilakukan adalah untuk mengevaluasi sejauh mana pelaksanaan rencana yang telah ditetapkan dapat berjalan.

Secara umum cara pengontrol yang dilakukan adalah memperbaiki (26.9\%) dan keluarga ini termasuk tidak miskin, sedangkan sebesar $20.0 \%$ adalah miskin. Sebesar $83.3 \%$ pekerjaan yang dikontrol ibu adalah anak dan segala urusan keluarga dan keluarga ini termasuk tidak miskin, sedangkan $75.0 \%$ adalah miskin. Sementara itu, sebesar $45.2 \%$ pekerjaan yang dikontrol ayah adalah mencari nafkah, dan keluarga ini tergolong tidak miskin, sedangkan $43.5 \%$ adalah miskin. Secara lengkap dapat dilihat pada Tabel 5.

Tabel 5: Sebaran Responden dalam Melakukan Pengawasan dan Tingkat Kesejahteraan

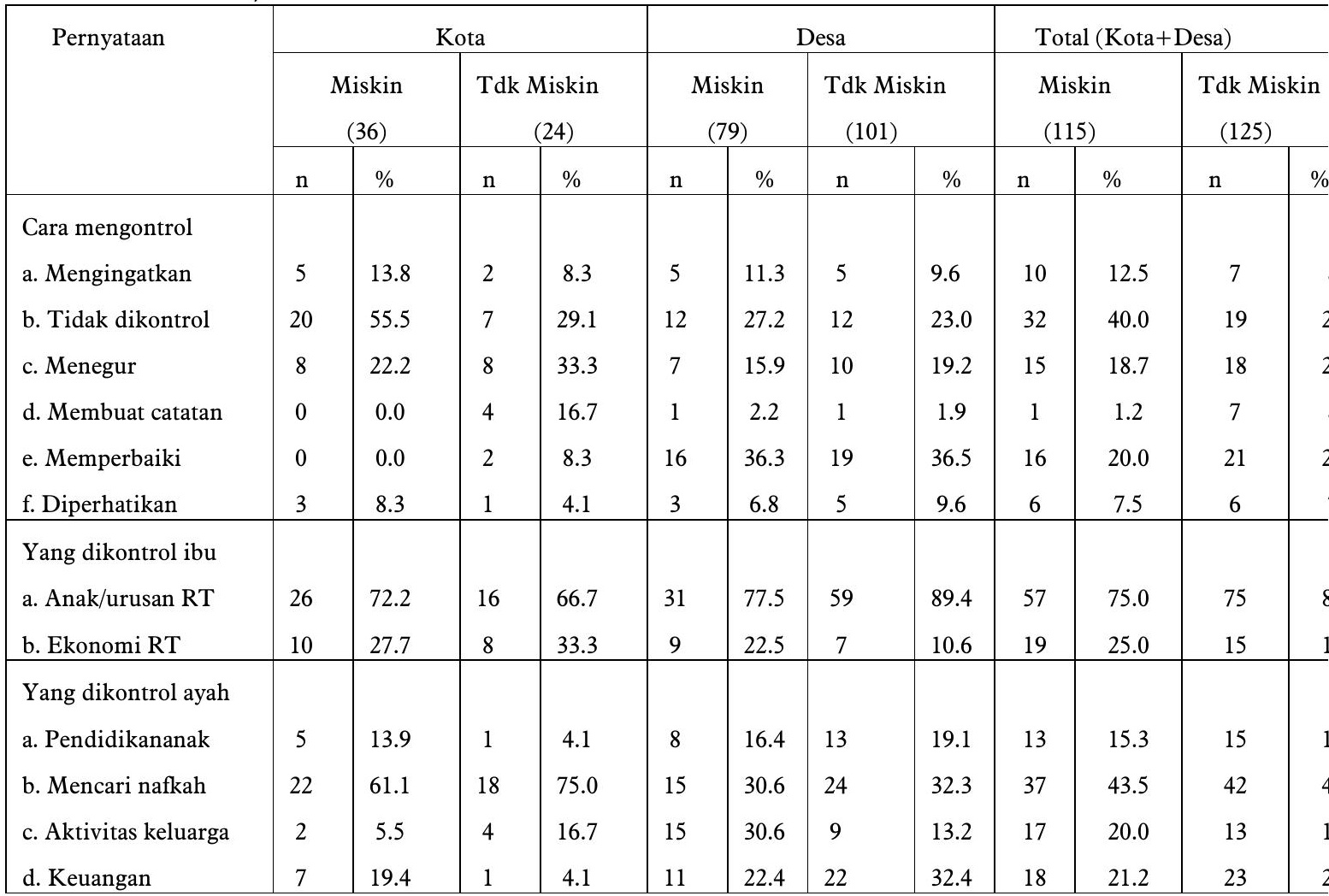

Pembuatan rencana yang terperinci, pengorganisasian, sampai pada pelaksanaan kegiatan sesuai dengan rencana. Kontrol yang baik terhadap kegiatan yang dilakukan akan sangat menunjang tercapainya tujuan hidup yang diinginkan. Hasil penelitian menunjukkan bahwa sebanyak $55.5 \%$ keluarga di kota tidak melakukan kontrol, sedangkan di desa $27.2 \%$, termasuk keluarga miskin.

\section{Faktor yang Berpengaruh Terhadap Manajemen Sumberdaya Keluarga}


Analisis dilakukan melalui beberapa faktor internal/eksternal yang mempengaruhi proses manajemen adalah jumlah anggota, umur $\mathrm{KK} /$ isteri, pendidikan $\mathrm{KK} /$ isteri, pendapatan, kepemilikan aset, sedangkan faktor eksternal yang mempengaruhi proses manajemen adalah tempat tinggal. Secara rinci dapat dilihat pada Tabel 6

Tabel 6: Faktor yang Mempengaruhi Perencanaan dalam Keluarga

\begin{tabular}{|l|c|c|c|}
\hline \multirow{2}{*}{ Variabel Bebas } & \multicolumn{3}{|c|}{ Perencanaan $(0=$ tidak, $1=$ ya $)$} \\
\cline { 2 - 4 } & $\beta$ & Sig & OR \\
\hline Jumlah Anggota & 0.050 & 0.552 & 1.051 \\
\hline Umur KK & 0.022 & 0.403 & 1.022 \\
\hline Umur Isteri & -0.045 & 0.124 & 0.956 \\
\hline Pendidikan KK & 0.134 & 0.232 & 1.143 \\
\hline Pendidikan Isteri & -0.204 & 0.076 & 0.818 \\
\hline Pendapatan & $3.510^{-7}$ & 0.373 & 1.000 \\
\hline Aset & 0.009 & 0.806 & 1.009 \\
\hline Lokasi $(1=$ kota, $0=\mathrm{kab})$ & 0.995 & $0.009 \star \star$ & 2.705 \\
\hline $\mathrm{R}^{2}$ & \multicolumn{3}{|c}{} \\
\hline $\mathrm{P}$ & \multicolumn{3}{|c|}{0.173} \\
\hline
\end{tabular}

Keterangan: $\star(p<0.01), \star \star(p<0.05), \star \star \star(p<0.1)$

Pada Tabel 48 di atas terlihat bahwa responden yang tinggal di kota memiliki peluang lebih tinggi 2.705 kali untuk melakukan perencanaan dibanding keluarga yang tinggal di.desa. Analisis regresi logistik menunjukkan bahwa pendidikan KK yang tinggi berpeluang lebih tinggi 1.373 kali untuk melakukan pembagian tugas dibanding $\mathrm{KK}$ yang tingkat pendidikannya rendah.

Contoh yang tinggal di kota berpeluang lebih tinggi 3.477 kali untuk melakukan pembagian tugas dibanding contoh yang tingal di desa. Pembagian tugas adalah distribusi kewenangan atau tanggungjawab kepada anggota sehingga tidak menjadi beban salah satu anggota, dengan begitu semua pekerjaan berjalan secara teratur, tanpa pembagian tugas yang jelas menyebabkan saling menunggu dan mengharapkan siapa yang sesungguhnya akan melaksanakan pekerjaan tersebut. Secara ronci dapat dilihat pada Tabel 7.

Tabel 7: Faktor yang Mempengaruhi Pembagian Tugas dalam Keluarga

\begin{tabular}{|l|c|c|c|}
\hline \multirow{2}{*}{ Variabel Bebas } & \multicolumn{3}{|c|}{ Pembagian Tugas $(0=$ tidak, $1=$ ya $)$} \\
\cline { 2 - 4 } & $\beta$ & Sig & OR \\
\hline Jumlah Anggota & 0.037 & 0.675 & 1.038 \\
\hline Umur KK & -0.023 & 0.627 & 0.967 \\
\hline
\end{tabular}




\begin{tabular}{|l|l|l|l|}
\hline Umur Isteri & 0.022 & 0.498 & 1.022 \\
\hline Pendidikan KK & 0.317 & $0.012^{\star}$ & 1.373 \\
\hline Pendidikan Isteri & 0.212 & 0.081 & 0.809 \\
\hline Pendapatan & $-6.710^{-7}$ & 0.207 & 1.000 \\
\hline Aset & -0.029 & 0.456 & 0.972 \\
\hline Lokasi (1=kab, 0=kota) & 1.246 & $0.001^{\star \star}$ & 3.477 \\
\hline $\mathrm{R}^{2}$ & \multicolumn{3}{|l}{0.172} \\
\hline $\mathrm{P}$ & \multicolumn{3}{|l}{} \\
\hline
\end{tabular}

Keterangan: ${ }^{\star}(\mathrm{p}<0.01),{ }^{\star \star}(\mathrm{p}<0.05),{ }^{\star \star \star}(\mathrm{p}<0.1)$

Hal ini di dukung oleh penelitian Rezeki (2006) bahwa dalam hal keuangan di atur oleh isteri baik ibu bekerja (65.1\% maupun ibu tidak bekerja (56.7\%). Penyediaan menu sehari-hari pada ibu bekerja (90.9\%) maupun ibu tidak bekerja (86.5\%). Persentase tertinggi pekerjaan domestik dilakukan oleh isteri baik yang bekerja (63.6\%) dan tidak bekerja (65.5\%), partisipasi suami cukup tinggi yaitu lebih dari separuhnya. Untuk pelaksanaan dimaksud adalah alokasi pendapatan dan alokasi waktu kegiatan. Keluarga contoh yang pendapatannya tinggi berpeluang 1.000 kali untuk tidak melakukan pengawasan atau kontrol dibandingkan dengan keluarga contoh yang memiliki pendapatan rendah Secara rinci dapat dilihat pada Tabel 8

Tabel 8: Faktor yang Mempengaruhi Pengawasan Kegiatan Keluarga

\begin{tabular}{|l|c|c|c|}
\hline \multirow{2}{*}{ Variabel Bebas } & \multicolumn{3}{|c|}{ Pengawasan (0=tidak, $1=$ ya) } \\
\cline { 2 - 4 } & $\beta$ & Sig & OR \\
\hline Jumlah Anggota & 0.160 & 0.212 & 1.173 \\
\hline Umur KK & -0.023 & 0.478 & 0.977 \\
\hline Umur Isteri & 0.018 & 0.630 & 1.0108 \\
\hline Pendidikan KK & 0.292 & 0.050 & 1.339 \\
\hline Pendidikan Isteri & -0.078 & 0.615 & 0.925 \\
\hline Pendapatan & $-1.3 \times 10^{-6}$ & $0.007 \star \star$ & 1.000 \\
\hline Aset & -0.006 & 0.897 & 0.994 \\
\hline Lokasi $(1=$ kab, $0=$ kota $)$ & -0.349 & 0.504 & 0.705 \\
\hline $\mathrm{R}^{2}$ & & 0.141 & \\
\hline $\mathrm{P}$ & \multicolumn{3}{|c}{} \\
\hline
\end{tabular}

Keterangan: ${ }^{\star}(\mathrm{p}<0.01),{ }^{\star \star}(\mathrm{p}<0.05),{ }^{\star \star \star}(\mathrm{p}<0.1)$ 


\section{Kesimpulan}

\section{KESIMPULAN DAN SARAN}

Adapun beberapa kesimpulan dalam tulisan ini adalah sebagai berikut:

1. Analisis Proses Manajemen Keluarga dalam Mencapai Kesejahteraan Keluarga. Sebagian besar responden memiliki perencanaan keluarga, sedangkan lebih dari separuh responden di kota melakukan pembagian tugas dan sebagian besar responden di desa tidak melakukan pembagian tugas. Sementara itu, lebih dari separuh responden di kota tidak melakukan pengontrolan, sedangkan sebagian kecil responden di desa saling mengingatkan.

2. Analisis Faktor yang Mempengaruhi Praktek Manajemen Keluarga Pendidikan KK yang tinggi dapat melakukan pembagian tugas, sedangkan keluarga dengan pendapatan tinggi melakukan pengontrolan atas kegiatan, sementara itu, responden di kota dapat melakukan perencanaan dan pembagian tugas

\section{Saran}

Adapun saran-saran yang dapat diberikan dalam tulisan ini adalah:

1. Dalam melakukan pemberdayaan keluarga miskin, tidak hanya dengan memberikan bantuan finansial, sebab pemberian finansial tanpa didukung dengan manajemen keluarga yang bagus, akan sia-sia bantuan yang diberikan. Oleh karena itu, perlu dilakukannya sosialisasi kognitif yang berkaitan dengan perencanaan, pembagian tugas, pelaksanaan dan pengontrolan;

2. Perlu ada penelitian lanjutan dalam rangka praktek dan simulasi manajemen keluarga sehingga apapun sumberdaya yang dimiliki akan dikelola dengan manajemen yang lebih moderen dan profesional.

\section{DAFTAR PUSTAKA}

Fraenkel \& Wallen. 1993. How To Design and Evaluate Research in Education Secon Edition. New York. Mc. Graw-Hill.Inc

Guhardja et al, 1992. Petunjuk Laboratorium Manajemen Sumberdaya Keluarga. Pusat Antar Universitas Pangan dan Gizi, Institut Pertanian Bogor

Hennekens, C.H., \& Buring, J.E. 1987. Epidemiology in Medicine. Little, Beown and Company. Boston/Toronto

Rambe, A, 2005. Alokasi Pengeluaran Rumahtangga dan Tingkat Kesejahteraan (Kasus di Kecamatan Medan Kota Sumatra Utara). Tesis Sekolah Pascasarjana IPB, Bogor 
Sajogyo, 1999. Memahami dan Menanggulangi Kemiskinan di Indonesia. Penerbit PT. Gramedia Widiasarana Indonesia. Jakarta.

Susanti.1999. Kebiasaan makan dan aktivitas fisik dalam hubunganya dengan gizi lebih pada murid taman kanak-kanak di Kodya Bengkulu (tesis) Bogor. Program Pascasarjana IPB

Sutopo, H.B. 1990. Metode Penelitian Kuantitatif Kerangka Dasar dan Orientasi Penelitian Sosial Budaya. Pusat latihan Action Research, Surakarta.

Soekirman, 1991. Dampak Pembangunan Terhadap Keadaan Gizi, Orasi Penerimaan Jabatan Guru Besar Luar Biasa Ilmu Gizi Fakultas Pertanian, IPB. Bogor

Setiawan, B, \& Muntaha, A. 2000. Metode Penelitian Komunikasi.Pusat Penerbitan Universitas Terbuka,Jakarta.

Supranto, J. 2000. Teknik Sampling untuk Survei dan Eksperimen. Rineka Cipta. Jakarta

Suhardjo, 1989. Sosio Budaya Gizi Pusat Antar Universitas Pangan dan Gizi. IPB

Tomagola., dalam Sugiarti. 1995. Perubahan dan Pergeseran Peran Keluarga Dalam Era Globalisasi. Makalah Kapita Selekta Sosiologi, UMM, Malang.

Walpole, R.E. 1995. Pengantar Statistik. Penerbit PT Gramedia Pustaka Utama, Jakarta 